\title{
Managerial leadership and interactional justice perceptions: An exploratory study
}

\author{
Zara Sabeen \\ Muhammad Ali Jinnah University, Islamabad, 835, street 104, G-9/4, Islamabad, Pakistan. \\ E-mail: Zarasabeen@hotmail.com. Tel: 92-51-3225126673. \\ Accepted 20 April, 2012
}

\begin{abstract}
The study explores the impact of leadership behavior in stimulating the perceptions of interactional justice. The behavioral elements of a leader's personality, such as integrity, consistency, communication and concern for others are studied for their influence upon the perceptions of interactional justice amongst the subordinates. Research conducted in the banking and telecom sectors of Pakistan, with a sample size of 777 gives a clear indication of a significant positive impact of the said group of leader behavior's sub-variables upon the dependant variable.
\end{abstract}

Key words: Servant leadership, trustworthy behavior, leader-member exchange.

\section{INTRODUCTION}

Managerial trustworthy behavior is defined as certain actions and interactions that are necessary on part of managers to be performed to engender employees' trust in them (Whitener et al., 1998). Trust as defined by Flores and Solomon (1998), is a 'social practice, defined by choices' also they say that 'trust is first of all an attitude, a feeling and an emotion'. And trustworthiness of a person is something that is recognized through the attitude and action, and not the speech. Hardin (1992), talks about the 'devices for commitment' that facilitate and make trustworthiness happen.

There are some important elements of managerial behavior discussed by researchers that ensure employee trust in them. Consistency in the behavior of manger has been pointed out as one of those important elements for the employees, by Buttler (1991), that helps in developing a trust based relationship. Behavioral integrity has been defined by Dasgupta (1988), as antecedent of integrity which result from the qualities of promise keeping and truth telling. The seemingly similar attributes of behavioral consistency and integrity are differentiated by Whitener et al. (1998), as trustworthiness or inexorableness of managers actions based on the past experiences and evenness between the managers' deeds and sayings. Employees have greater trust in their managers when they hey have more participation in decision making (Driscoll, 1978) and control sharing is an indicator of trust and respect for the employees (Rosen and Jerdee, 1977) which helps in developing healthy relationship amongst the boss and subordinate. Another important factor is manager's concern for the employees. Manager should be concerned about the employee needs and sensitivities as well (Lind, 1992), be there to help them and not exploiting them.

Interactional justice, which is sometimes interchangeably used for procedural justice, due to the fact that normally when the subordinates are using the term, they are generally talking about the quality of treatment received by their supervisors (Bies, 2001). It has a powerful role in deciding employee receptivity towards any system and perceptions of fairness. It has two basic components or segregations in research namely, interpersonal and informational justice.

Bies and Moag (1986) have described rules that are decisive to judge the fair treatment from the supervisor. According to them the treatment should be based on truthful exchange of information, adequate explanation, respect for the subordinate, and decency. The former two constitute the informational part of interactional justice, while the later ones describe the interpersonal justice (Cloquitt, 2001).

According to Kickul et al. (2002), interactional justice (interpersonal sensitivity), is the variable which is more influential and having more impact in terms of how worse the employees would react to a negative intrinsic outcomes as compared to the procedural part of the policies and procedures. Conversely, when more tangible, extrinsic outcomes are breached, employee 
reactions are driven by negative perceptions of procedural justice. Employees appear to be less forgiving for unfair procedures when outcomes are easily quantifiable and short-term in nature. According to the study conducted by Masterson et al. (2000), there is strong relationship between interactional justice and both job satisfaction and supervisor-directed organizational citizenship behavior (OCB).

The mediating factor in this relationship is leadermember exchange. It suggests that the social exchange theory has a strong connection with the justice explanations and that the interactional justice is mediated by the leader member exchange relationship. It again strengthens the proposition of managerial behavior contributing to the stimulation of positive perception regarding the employee treatment by the supervisor. In this context an important contributing and decisive factor is the self-esteem level of the employees.

According to Wiesenfeld et al. (2007), those with high self esteem, value justice and fairness more than those with low self esteem and they are more committed to the organization as well. So, we conclude that positive leadership behaviors not only help in developing and maintaining healthy and positive working relationship but also facilitate the creation of the perception of just environment at the workplace.

\section{LITERATURE REVIEW}

Chemers (2002) defined leadership as a social influence process. Initially, leadership was presented as the idea of 'hereditary genius' by Galton (1869). Galton also presented the idea of born leadership that cannot be developed if it is not there as an inbuilt ability. This is idea was the basic emerging point for the theories associated to the attributes and traits of the leader. For example the trait theory of leadership is one of the earliest works in this direction, which assumes leadership to be a function of individual attributes.

In 1940's and 1950's there was a realization that different situations might affect the leadership abilities of the individuals. In 1964, the managerial Grid model of leadership styles was presented. The situational and contingency models include; Fiedler's contingency model, decision model by Vroom and Path-Goal theory by Robert House (1971).

There was emergence of behavior and style theories of leadership, including, McClleland's theory, group decision making theory and project management theories. That era particularly emphasized upon the leadership styles such as bureaucratic and democratic styles.

The functional leadership theory presented by Hackman and Walton (1986), described the behaviors required of the team leaders. The team leader, to them, is the one who can deliver and contribute to the objectives of the team. The concept of transactional leadership
(Burns, 1978), gives a leader the control to recompense or punish the employees in order to correct the mistakes and/or to improve the results. The transformational leader (Burns, 1978) on the other hand values communication with subordinates and uses it as a medium for goal focus an achievement.

One of the famous books on the topic of leadership, titled 'The Seven Pillars of Servant Leadership' was written by Sipe and Frick (2009). In this book, the characteristics of servant leaders are mentioned as: "servant-leaders are individuals of character, they put people first, they are skilled communicators, they are compassionate collaborators, they use their foresight, they are systems thinkers, and they exercise moral authority".

It has been suggested that management and leadership are inseparable (kotter, 1990) and they are integral part of each other, despite all the differences between the two. For this reason, the modern concepts of leadership include the role of manager as a leader, for example managerial leadership. Managerial leadership is the most relevant and consistent in terms of requirements to the servant leadership concepts, whereby a leader (who is the manager as well) peruses the goals by directly communicating and showing concern for the employees.

The organizations are thought to be the realities that are constructed socially (Morgan, 1986). And the leaders in the organization are supposed to be the ones who translate this reality (DePree, 1989: 19) to the employees in an honest and transparent manner. And the leader who is able to translate these realities is an effective leader who can actually play a role for organizational progress and success (Caldwell et al., 2002). Caldwell et al. (2002: 39) along with defining and translating if a leader is able to influence the organizational meanings, he has control over the company's fate and becomes the integral part of the company. As this interpretation, for employees is an ethical duty of the leader. It is also a determinant of the quality of leadership and ethics in the organization, because it totally depends upon the leaders own values and ethical standards in which he translates the organizational meanings (Worden, 2003). For this reason leaders are to be blamed or praised for being responsible for this standard setting phenomenon. Also, it makes them vulnerable to the perceptions of integrity and honesty. One of the basic behavioral element serving as the pillar in the personality of a leader is behavioral integrity.

Simons (1999: 90) defines behavioral integrity as "the perceived degree of congruence between the values expressed by words and those expressed through action". Credibility, like trust, is a future oriented attribute which can also be affected by behavioral integrity of a person or a party. Credibility is mainly focused at anticipating future course of action, with certain perception of reliability of the speaker's words, in terms of 
their chances to be translated into action. Further, credibility is affected by evaluation of competence, genuineness, and compassion, while behavioral integrity considers only the past data on the alignment of the speaker's pattern of speech and action. The third important factor that should be the part of behavior of a leader is his concern for the employees, as he is the representator of the organization's concern for its employees.

An organizations concern for its employees which is evident through the level of care for employee welfare, equity in the payments, fairness in treatment, concern for their satisfaction and sharing any organizational success with them are the ways through which the organization can show its interest to the employees (Eisenberger et al., 1986, 1990; Moorman et al., 1998; Mowday et al., 1984; Organ, 1990; Orpen, 1995; Pfeffer, 1981; Williams and Anderson, 1991) and this phenomenon is known as perceived organizational commitment (OCE) which serves as a tool to enhance responsible behavior on the part of employees due to increased involvement (Eisenberger et al., 1990).

Moorman et al. (1998) and Shore and Wayne (1993) established that the perceptions of OCE have an important role to make employees more careful in carrying out their job responsibilities.

\section{Interactional justice}

For long time in history, procedural and interactional justice had been treated as the interchangeable concepts. In the beginning of the last decade it was presented as a distinct field of organizational justice by a number of researchers (For example, Colquitt, 2001) and Meta analytic (For example, Cohen-Charash and Spector, 2001; Colquitt et al., 2001).

Interpersonal treatment, in addition to formal processes, has been found to influence workers' justice perceptions. It can be distinguished from the procedural justice since the employees have more sensitivity towards the amount of respect, honor and dignity they receive from their bosses. Providing employee with true and honest information is also a part of it. Anything contrary it in the interactions, like the lack of respect or dishonesty in information provision will be assumed as interactional unfairness. Interactional justice is responsible for various important organizational outcomes (Cohen-Charash and Spector, 2001).

Majority of negative perceptions prevailing at the workplace have been found to emerge out of the situations and dealings that carry the senses of unequal and unfair treatment and hence interactional justice is most influential as compared to the procedural and distributive justice (Mikula et al., 1990).

Mikula et al. (1990) confirmed that such treatments in which the managers do not care for the dignity of the employee, be harsh to them and indulge in the breach of trust, are denoted as unfair interactions. People really feel hurt and negative if they are not being given consideration by others around, being mistreated, being exploited etc (Messick et al., 1985).

The requisites for employee's perception of fairness, according to researchers (Leventhal, 1976; Leventhal et al., 1980) are the procedures that are consistent, provide true information, equitable, based on rules, allow voice and are bias free. Contrary to unfairness perceptions, the results of positive perceptions are the behaviors like, $\mathrm{OCB}$, Trust and organizational commitment (Colquitt et al., 2001).

According to researchers the perceptions of interactional justice are more relevant to explain the counter productive work behaviors such as intentions of revenge from the supervisor, reduction of cooperation behavior and aggression against the manager etc. It has also been found that the procedural justice can reduce the impact of low outcome favorability. Since we know that these perceptions are very helpful to develop and maintain trust based relationship among the employee and employer, so there is need to adopt an approach where the employer emphasizes upon developing these social networks (Degoey, 2000; Lamertz, 2002).

In order to have a positive image in the eye of these social networks leader has to play an important role, according to Erdogan and Liden (2002) the font from which all the perceptions $f$ interactional justice originate, at the workplace, is the leader, and particularly in the pattern of leader's dealing and treatment of his employees (Masterson et al., 2000).

Also, according to Bies (2001), interactional justice is strongly associated with the conscious or unconscious assessment of the leader in the mind of subordinate, and trust in authorities and quality of leader-member exchange as well (Cohen-Charash and Spector, 2001; DeCremer, 2007). But it also has to be kept in mind that these perceptions and interpretations may not be the same universally. And it is not necessary that these might be related to the work behaviors as well.

\section{Research question}

Is interactional justice perception affected by different behaviors shown by the managerial leadership?

\section{Hypotheses development}

Leadership behavior is given utmost importance in the literature because managerial role is considered to be a leader's role. The major reason for this significance being associated to it is the influence (Waclawski and church, 1999) embedded in it.

The evidences that people receive during the interactions and daily course of action are of decisive importance for the employees. They see, perceive and 
Table 1. Descriptives.

\begin{tabular}{lcccc}
\hline & Minimum & Maximum & Mean & Std. Deviation \\
\hline IJ & 1.22 & 4.78 & 3.7220 & 0.64233 \\
MB & 1.43 & 4.63 & 3.6977 & 0.57533 \\
Valid N (listwise) (777) & & & & \\
\hline
\end{tabular}

$\mathrm{IJ}=$ interactional justice, $\mathrm{MB}=$ managerial behavior.

develop their judgments based on these experiences. These judgments then act as stimulus for their own behaviors. The person in authority with whom they interact daily and they perceive responsible for their own position and value at workplace are always under their ruthless screening.

The most important aspect under this screening is the behavior of these superiors. What is their own credibility, are they trustworthy (e.g. Caldwell et al., 2009), are they really the ones whom they can call as their stewards and the caretakers of the employee's interests (De Cremer and Hiel, 2006), do they develop and maintain fair work relationships with all of their subordinates? These and all such characteristics have been discussed in the previous literature as the antecedents of managerial trustworthiness and a trust-based relationship amongst the manager and the employees.

People perceive the moral leaders to be the ones who can maintain justice. It is widely believed that the people who have certain personality characteristics, evident through their behavioral display, are the ones who can be trusted, are fair and maintain justice (Brown and Trevino, 2006). Based on these evidences, the following set of hypotheses regarding the leadership behavior, are developed.

$\mathbf{H}_{1}$ : There is a positive causal relationship between managerial behavior and perceptions of interactional justice.

$\mathbf{H}_{1 \mathrm{a}}$ : There is a positive causal relationship between behavioral integrity and perceptions of interactional justice.

$\mathbf{H}_{1 \mathrm{~b}}$ : There is a positive causal relationship between sharing and delegation of control and perception $s$ of interactional justice.

$H_{1 c}$ : There is a positive causal relationship between communication and perceptions of interactional justice.

$\mathbf{H}_{1 \mathrm{~d}}$ : There is a positive causal relationship between managerial behavior and perceptions of interactional justice.

$\mathbf{H}_{1 \mathrm{e}}$ : There is a positive causal relationship between demonstration of concern and perception $s$ of interactional justice.

\section{INSTRUMENT}

For managerial behavior dimensions, the items for the questionnaire are derived from Moorman (1991), and Oldham and
Cummings (1996). The items of interactional justice scale are derived from Scarpello and Vandenber (1987).

\section{Sample and response rate}

The sample of research is derived of the banking and telecommunication sectors of Pakistan. The data has been collected from four major cities of Pakistan namely, Karachi, Lahore, Islamabad and Rawalpindi. Sampling is done on the basis of convenience.

The target sample comprises of the employees from middle and lower managerial positions and the non-managers of the companies. In total 1000 survey forms were distributed, out of which, 777 were received back, with a response rate of $77 \%$.

\section{RESULTS AND DISCUSSION}

\section{Descriptive statistics}

The mean values of both variables that is, managerial behavior and interactional justice lie above 3.5 values table 1, which is closer to the 'agree' category of the instrument scale. So, all the mean values are positive and significant.

If all the components of the variables or the sub variables are considered separately, the descriptive statistics still show the positive results, given in Table 2 . The correlation values of all the variables are significant. The correlation coefficient for managerial behavior vs. interactional justice is 0.63 , which is a significant value. Taking into account the sub variables of managerial behavior, the correlation coefficient values range from 0.72 to 0.98 , showing highly significant association among all the variables.

\section{Correlations}

The correlation values of the variables and sub variables are significant table 3 . The correlation coefficient between managerial behavior and interactional justice is 0.63 , which is a significant value, showing that the relationship between the two variables is a strong one and is in positive direction. Hence it can be said that increase in one of the two variables causes in increase in the other, or the managerial behavior and the perceptions of interactional justice go hand in hand. If the manager shows the positive behaviors, the employee perceptions 
Table 2. Descriptives of the sub variables.

\begin{tabular}{lcccc}
\hline & Minimum & Maximum & Mean & Std. Deviation \\
\hline $\mathrm{BC}$ & 3.15 & 3.70 & 3.3300 & .22494 \\
$\mathrm{BI}$ & 3.32 & 3.80 & 3.6160 & .20354 \\
Com & 3.69 & 3.99 & 3.8400 & .12570 \\
DemoC & 3.48 & 4.38 & 3.9680 & .33730 \\
Valid N (listwise) & & & & \\
\hline
\end{tabular}

$\mathrm{BC}=$ behavioral consistency, $\mathrm{BI}=$ behavioral integrity, $\mathrm{Com}=$ communication. DemoC $=$ demonstration of concern.

Table 3. Correlation.

\begin{tabular}{llll}
\hline & & IJ & MB \\
\hline IJ & Pearson correlation & 1 & $0.630\left(^{* *}\right)$ \\
& Sig. (2-tailed) & & 0.000 \\
& $\mathrm{~N}$ & 777 & 777 \\
& & & \\
MB & Pearson correlation & $0.630\left(^{* \star}\right)$ & 1 \\
& Sig. (2-tailed) & 0.000 & \\
& $\mathrm{~N}$ & 777 & 777 \\
\hline
\end{tabular}

about the interactional justice also get more and more positive. Again considering the sub-variables of managerial behavior, the correlation coefficient values still remain highly significant.

\section{Regression}

The significant values of correlation further allow advancing further testing of the causal relationship amongst the variables. In order to find out the mediating or non-mediating role of interactional justice, the following paths and equation were used for the regression analysis:

Managerial behavior

Interactional justice perceptions

Regression equation:

$Y=\beta+\beta 1 X 1+\varepsilon$

Where; $Y=$ IJ (interactional justice/dependent variable), $\beta$ $=$ constant, $\beta 1=$ coefficient of managerial behavior, $X 1=$ managerial behavior (predictor variable), $\varepsilon=$ error termregression results show that interactional justice perceptions are affected by managerial behavior.

The R2 value of the model is 39.6, while the beta coefficient for Managerial behavior is .703 , which is highly significant (table 4.1- 4.3).

\section{Hypothesis testing}

Hypothesis 1 assumed a causal relationship between the managerial behavior and the interactional justice. Theory suggests that the leaders with certain personality traits and with a moral and spiritual dimension are able to create an image as the ones who are fair in their treatments, balance the relationships with their subordinates and make decisions based on justice. The beta coefficient value of managerial behavior being 0.70 shows its significant impact upon the development of perception related to interactional justice in the minds of employees. The $R^{2}$ value in this case is 0.39 , depicting the $39 \%$ explanation of variation in interactional justice due to managerial behavior, which is a significant value. The regression between the two, having managerial behavior as predictor and interactional justice as the outcome confirms the hypothesis to be true. Thus we accept the hypothesis $1\left(\mathrm{H}_{1}\right)$ and reject the null hypothesis. When the sub hypotheses of $\mathrm{H}_{1}$ are considered, there are mixed results.

Behavioral consistency and behavioral integrity are found to be the most influential variables, with coefficient values 0.61 and 0.93 , respectively. Demonstration of concern has a very nominal effect, while communication has negative effect on interactional justice perceptions. Having these results, the sub hypotheses $\mathrm{H}_{1 \mathrm{a}}$ and $\mathrm{H}_{1 \mathrm{~b}}$ are accepted while the rest are rejected. The possible reasoning and interpretation of the results is given in the discussion separately.

\section{DISCUSSION}

In the literature review, it was found out that different 
Table 4.1. Regression model summary.

\begin{tabular}{ccccc}
\hline Model & R & R square & Adjusted R square & Std. error of the estimate \\
\hline 1 & $0.630(\mathrm{a})$ & 0.397 & 0.396 & 0.49923 \\
\hline aPredictors: (Constant), MB. & & &
\end{tabular}

Table 4.2 Coefficients(a)

\begin{tabular}{llccccc}
\hline \multirow{2}{*}{ Model } & & \multicolumn{2}{c}{ Unstandardized coefficients } & Standardized coefficients & $\mathbf{t}$ & Sig. \\
\cline { 3 - 7 } & & $\mathbf{B}$ & Std. Error & Beta & B & Std. Error \\
\hline 1 & (Constant) & 1.122 & 0.117 & & 9.623 & 0.000 \\
& MB & 0.703 & 0.031 & 0.630 & 22.575 & 0.000 \\
\hline
\end{tabular}

aDependent variable: IJ.

Table 4.3. Regression $\mathrm{b} / \mathrm{w}$ OCB and sub variables of managerial behaviors.

\begin{tabular}{|c|c|c|c|c|c|c|}
\hline \multirow{2}{*}{ Model } & & \multicolumn{2}{|c|}{ Unstandardized coefficients } & \multirow{2}{*}{$\begin{array}{c}\text { Standardized coefficients } \\
\text { Beta } \\
\end{array}$} & \multirow{2}{*}{$\begin{array}{l}\mathrm{t} \\
\mathrm{B}\end{array}$} & \multirow{2}{*}{$\begin{array}{l}\text { Sig. } \\
\text { Std. Error }\end{array}$} \\
\hline & & $B$ & Std. Error & & & \\
\hline \multirow[t]{5}{*}{1} & (Constant) & 6.531 & 0.000 & & . & \\
\hline & $\mathrm{BC}$ & 2.526 & 0.000 & 1.745 & . & . \\
\hline & $\mathrm{BI}$ & 1.799 & 0.000 & 1.124 & . & . \\
\hline & Com & -4.489 & 0.000 & -1.733 & . & . \\
\hline & DemoC & -0.073 & 0.000 & -0.076 & . & . \\
\hline
\end{tabular}

aDependent variable: OCB.

attitudes, behaviors, and/or competencies of a superior or a manager are held to be of worth in the eyes of the followers or the subordinates. Also, the concept of the leader and manager are no more the separate constructs. A manager has to be a leader in order to be an effective manager. And this concept of managerial leadership is also getting more influenced by the theories of servant leadership. As it is believed that leadership is not a mere position, rather it has more to do with the action and the leader has to translate the vision and get the people carry it and work according to it.

The results also support the same propositions of theory, confirming that the behaviors suggested for the study that all deal with interpersonal treatments and dealings are very important for the employees. In order to believe that the leadership/management is effective and hence to be followed and obeyed, employees put great emphasis upon the spiritual values manifested through behavior by them (Reave, 2005).

The subordinates give value to the treatments they receive from their superiors, and their judgments about the boss depend upon the quality of those. The findings partially support hypothesis 1 and its sub hypotheses, showing that all the behaviors that is, behavioral integrity, behavioral consistency, communication, and demonstration of concern are all important for an employee to have the fairness perceptions during the interactions.

It is clear that the correlation among interactional justice and all the components of managerial behaviors is highly significant (above 0.90 for all), but it is higher in case of the components that relate more to the interactional side of it (that is, communication, and showing concern), further strengthening the argument. But when the regression is run, the results are different.

Behavioral integrity is found to be the most influential variable with the highest coefficient value $(0.93)$, while communication has a negative coefficient value $(-0.37)$. Also the coefficient value of concern is very low that is, 0.087 . These results might have the social and cultural interpretations. In our culture the personality and its reputation (conforming to the religious and ethical values) is very important. And these perceptions are not very easily distorted, unless a very open and serious breach is committed. So, behavioral integrity once established is the main contributing factor towards the perceptions of interactional justice by the manager.

On the other hand, more communication is often seen as a tool of impression management from the employee side, while as a part of lobbying, politics and favoritism from the manager/boss side. For that reason it might have the negative impact on the interactional justice perceptions.

The findings are consistent with the findings of Reave (2005), Fry (Vitucci), and Cedillo (2005) and others in the field of spiritual leadership and transformational leadership (Burns, 1978; Bass, 1985; Bass and 
Stiedmeire, 1999 etc).

Weaver et al. (2005) also found the characteristics of ethical leadership such as honesty, fairness and caring to be positively influencing employee attitudes and perceptions.

The results show that the behaviors alone are not sufficient. The personal integrity or behavioral consistency cannot force the employees to perform and behave in the required manner. Also, concern and communication are not enough alone. The same has been verified by Ambrose et al. (2007) that it is basically the event attitude that generates the positive or negative perception of justice. Until or unless the employees see these behaviors operative in the interactions and they have the confidence that justice and fairness is being maintained, these behaviors would not make the manager as influential as he would be in the case of its presence. In other words, the ethical and moral standing of the superior is very important for the employees, but what is even more important is its practical demonstration in the daily routines and actions.

Research demonstrates that interactional justice affects certain attitudes such as trust in supervisor, supervisor satisfaction, and trust in management (Ambrose and Schminke, 2003; Aryee et al., 2002; Cohen-Charash and Spector, 2001; Pillai et al., 1999).

\section{REFERENCES}

Ambrose M, Ronald LH, Shankar G (2007). The relationship between justice and attitudes: An examination of justice eVects on event and system-related attitudes. Organ. Behav. Human Decision Proc.,103: 21-36

Ambrose ML, Schminke M (2003). Organization structure as a moderator of the relationship between procedural justice, interactional justice, POS and supervisory trust. J. Appl. Psychol., 88: 295-305.

Aryee S, Budhwar PS, hen ZX (2002). Trust as a mediator of the relationship between organizational justice and work outcomes: Test of a social exchange theory. J. Organ. Behav., 23: 267-285.

Bass BM (1985). Leadership and performance beyond expectations. New York: Basic Books.

Bass BM, Steidlmeier P (1999). Ethics, character, and authentic transformational leadership behavior. The Leadership Q. 10: 181217.

Bies RJ (2001). Interactional (in) justice: The sacred and the profane. In: Greenberg J \& Cropanzano R (Eds.), Advances in organizational justice. Stanford CA: Stanford University Press pp.89-118.

Bies RJ, Moag JS (1986) Interactional justice: Communication criteria of fairness. In: Lewicki RJ, Sheppard BH, \& Bazerman MH (Eds.), Research on negotiation in organizations. Greenwich CT: JAI Press 1:43-55.

Brown ME, Treviño LK (2006a). Charismatic leadership and workplace deviance. J. Appl. Psychol. 91:954-962.

Caldwell C, Bischoff SJ, Karri R (2002). 'The Four Umpires: A Paradigm for Ethical Leadership', J. Bus. Ethics 36:153-163.

Caldwell C, Davis B, Devine JA (2009). 'Trust, Faith, and Betrayal: Insights from Management for the Wise Believer', J. Bus. Ethics 89(1):103-114.

Chemers MM (2002). Efficacy and effectiveness: Interpreting models of leadership and intelligence. In: Riggio R, Murphy S \& Pirozzolo FJ (Eds.), Multiple Intelligences and Leadership. Mahwah, NJ: Lawrence Erlbaum Associates pp.139-160.
Cohen-Charash Y, Spector PE (2001). The role of justice in organizations: A meta-analysis. Organ. Behav. Human Decision Proc. 86: 278-324.

Colquitt JA (2001). On the dimensionality of organizational justice: A construct validation of a measure. J. Appl. Psychol. 86:386-400.

Colquitt JA, Conlon DE, Wesson MJ, Porter COLH, Ng K (2001). Justice at the millennium: A meta-analytic review of 25 years of organizational justice research. J. Appl. Psychol. 86:425-445.

Dasgupta P (1988). Trust as a commodity. In D. Gambetta (Ed.), Trust: Making and breaking cooperative relations. Cambridge, MA: Basil Blackwell pp.49-72.

De Cremer D, Van Hiel A (2006). When it matters to me that you are treated fairly: Effects of other's fair treatment as a function of other's willingness to help. Organ. Behav. Human Decision Proc. 100(2):231249.

DeGoey P (2000). Contagious justice: Exploring the social construction of justice in organizations. Res. Organ. Behav. 22:51-102.

DePree M (1989). Leadership is an Art (Doubleday, NY) p.136.

Driscoll JW (1978). Trust and participation in organizational decision making as predictors of satisfaction. Acad. Manag. J. 21:44-56.

Eisenberger R, Huntington R, Hutchison S, Sowa D (1986). Perceived organizational support. J. Appl. Psychol. 71:500-507.

Eisenberger R, Fasolo P, Davis-LaMastro V (1990). 'Perceived organizational support and employee diligence, commitment, and innovation', J. Appl. Psychol. 75:51-59.

Erdogan B, Liden RC (2002). Social exchanges in the workplace: A review of recent development and future research directions in leader-member exchange theory. In: Neider LL \& Schriesheim CA (Eds.), Leadership: Greenwich, CT: Information Age Publishing pp.65-114.

Flores F, Solomon RC (1998). 'Creating Trust', Bus. Ethics Q. 8(2):205232

Fry L, W, Vitucci S, Cedillo M (2005). Spiritual leadership and army transformation: Theory, measurement, and establishing a baseline. The Leadership Q. 16: 835-862.

Galton F (1869). Hereditary Genius: An Inquiry into Its Laws and Consequences. London: Macmillan, (Reprinted, Bristol: Thoemmes Press, 1999). p.1.

Hackman JR, Walton RE (1986). Leading groups in organizations. In P. S. Goodman (Ed.), Designing effective work groups. San Francisco: Jossey-Bass.

Hardin R (1992). The Street-Level Epistemology of Trust, in Analyse und Kritik. pp. 152-176.

House RJ (1971). A path-goal theory of leader effectiveness. Adm. Sci. Q. 16:321-339.

Kickul J, Lester WS, Finkl J (2002). Promise Breaking during Radical Organizational Change: Do Justice Interventions Make a Difference? Special Issue: Brave New Workplace: Organizational Behavior in the Electronic Age, Published by: John Wiley \& Sons. J. Organ. Behav. 23(4):469-488

Kotter JP (1990). Force For Change: How Leadership Differs from Management. Free Press.

Lamertz K (2002). The social construction of fairness:Social influence and sense making in organizations. John wiley and sons. J. Organ. Behav. 23: 19-37.

Leventhal GS (1976a). Fairness in social relationships. In: Thibaut JW, Spence JT \& Carson RC (Eds.), Contemporary topics in social psychology. Morristown, NJ: General Learning Press pp.211-239.

Leventhal GS, Karuza, J, Fry WR (1980) Beyond fairness: A theory of allocation preferences. In: Mikula G (Ed.), Justice and social interaction. New York: Springer-Verlag pp.167-218.

Lind E, Earley PC (1992). Procedural justice and culture. Int. J. Psychol. 37:227-242.

Masterson SS, Lewis K, Goldman BM, Taylor MS (2000). Integrating justice and social exchange: The differing effects of fair procedures and treatment on work relationships. Acad. Manag. J. 43:738-748.

Masterson SS, Lewis K, Goldman BM, Taylor MS (2000). Integrating justice and social exchange: The differing effects of fair procedures and treatment on work relationships. Acad. Manag. J. 43:738-748.

Messick DM, Bloom S, Boldizar JP, Samuelson CD (1985). Why we are fairer than others. J. Exp. Soc. Psychol. 21:480-500.

Mikula G, Petrik B, Tanzer N (1990). What people regard as unjust: 
Types and structures of everyday experiences of injustice. Eur. J. Soc. Psychol. 20:133-149.

Moorman RH (1991). Relationship between organizational justice and organizational citizenship behaviors: Do fairness perceptions influence employee citizenship? J. Appl. Psychol. 76(6):845-855.

Moorman RH, Blakely GL, Niehoff BP (1998). Does perceived organizational support mediate the relationship between procedural justice and organizational citizenship behavior? Acad. Manag. J. 41:351-357.

Morgan G (1986). Images of Organization (Sage, Newbury Park, CA).

Mowday RT, Porter LW, Steers RM (1984). Employee-Organization Linkages: The Psychology of Commitment, Absenteeism and Turnover. Academic Press, New York.

Oldham GR, Cummings A (1996). Employees creativity: Personal and contextual factors at work. Acad. Manag. J. 39(3): 607-634.

Shore LM, Wayne SJ (1993). Commitment and employee behavior. J. Appl. Psychol. 78:774-780.

Rosen B, Jerdee TH (1977). Influence of subordinate characteristics on trust and use of participative decision strategies in a management simulation. J. Appl. Psychol. 62(5):628-631.

Organ DW (1990). The motivational basis of organizational citizenship behavior. In: Stawand BM, Cummings LL (eds.), JAI Press, Greenwich, CT. Res. Organ. Behav. (12):43-72.

Orpen C (1995). 'The effects of exchange ideology on the relationship between perceived organizational support and job performance. J. Soc. Psychol. 134:407-408.

Pfeffer J (1981). Management as symbolic action: The creation and maintenance of organizational paradigms.In: Cummings L, Staw B eds. JAI Press, Greenwich, CT. Res. Organ. Behavr. 3:1-52.

Pillai R, Schriescheim CA, Williams ES (1999). Fairness perceptions and trust as mediators for transformational and transactional leadership: A two-sample study. J. Manag. 25: 897-933.
Reave L (2005). Spiritual values and practices related to leadership effectiveness. Leadersh. Quart. 16:655-687

Simons TL (1999). Behavioral Integrity as a Critical Ingredient for Transformational Leadership. J. Organ. Change 12(2):89-104.

Sipe WJ, Frick MD (2009). Seven Pillars of Servant Leadership: Practicing the Wisdom of Leading by Serving. Paulist Pr.

Waclawski J, Church AH (1999). The 4-3-2-1 coaching modelat the meeting of the academy of management conference. Chicago II.

Weaver GR, Treviño LK, Agle B (2005). Somebody I look up to": Ethical role models in organizations. Organ. Dyn. 34:313-330.

Whitener EM, Brodt SE, KorsgaardJ MA, Werner M (1998). Managers as initiators of trust:A $n$ exchange relationship framework for understanding managerial trustworthy behavior. Acad. Manag. Rev. 23:513-530.

Wiesenfeld MB, Swann JRBW, Brockner J, Bartel AC (2007). Is more fairness always preferred? Self- esteem moderates reactions to procedural justice. Acad. Manag. J. 50(5):1235-1253

Williams LJ, Anderson SE (1991). Job satisfaction and organizational commitment as predictors of organizational citizenship and in-role behaviors. J. Manag. 17:601-617.

Worden S (2003). The Role of Integrity as a Mediator in Strategic Leadership: A Recipe for Reputational Capital, Springer. J. Bus. Ethics 46(1):31-44. 